\title{
Niewydolność serca jako manifestacja izolowanego niescalonego mięśnia prawej i lewej komory
}

\section{Heart failure as a manifestation of left and right ventricular non-compaction}

\author{
Małgorzata Jamro ${ }^{1}$, Mateusz Marek Wiśniowski ${ }^{1}$, Andrzej Curzytek ${ }^{1}$, \\ Wiesław Guz ${ }^{2,3}$, Agnieszka Kostkiewicz ${ }^{2,3}$ \\ ${ }^{1}$ Oddział Kardiologiczny Samodzielnego Publicznego Zakładu Opieki Zdrowotnej MSW w Rzeszowie \\ ${ }^{2}$ Katedra Elektroradiologii, Instytut Pielęgniarstwa i Nauk o Zdrowiu, Wydział Medyczny Uniwersytetu Rzeszowskiego \\ ${ }^{3}$ Kliniczny Zakład Radiologii i Diagnostyki Obrazowej Szpitala Wojewódzkiego Nr 2 w Rzeszowie
}

\section{Streszczenie}

W niniejszej pracy przedstawiono opis przypadku pacjenta z niewydolnością serca, u którego rozpoznano niescalony mięsień obu komór. Podejrzenie ostatecznego rozpoznania wysunięto na podstawie całokształtu obrazu klinicznego oraz badania echokardiograficznego. W rezonansie magnetycznym ostatecznie potwierdzono rozpoznanie niescalonego mięśnia prawej i lewej komory. Pacjent został skierowany do implantacji kardiowertera-defibrylatora ze względu na obserwowany w EKG metodą Holtera całkowity blok przedsionkowo-komorowy. Obecnie chory jest pod systematyczną obserwacją.

Słowa kluczowe: rozpoznanie, niescalony mięsień komór, rezonans magnetyczny

Folia Cardiologica 2016; 11, 4: 334-337

\section{Wstęp}

Niescalony mięsień lewej komory, określany również jako kardiomiopatia gąbczasta, opisano po raz pierwszy w 1984 roku. Rozpoznanie choroby warunkuje stwierdzenie obecności nadmiernie beleczkowanego, niescalonego miokardium lewej komory układającego się z częścią scaloną w charakterystyczną dwuwarstwę. W około 50\% przypadków może również przebiegać z zajęciem mięśniówki prawej komory. W całokształcie obrazu klinicznego dominują objawy niewydolności serca, zaburzeń rytmu oraz zatorowości obwodowej. W niniejszej pracy przedstawiono przypadek 54-letniego mężczyzny, którego pierwszą manifestacją niescalonego mięśnia obu komór była niewydolność serca.

\section{Opis przypadku}

Mężczyzna 54-letni, palący tytoń, został przyjęty na Oddział Kardiologiczny z powodu narastającej od kilku tygodni duszności. Chory dodatkowo zgłaszał pogorszenie tolerancji wysiłku od około roku, dotychczas niediagnozowane. Wywiad rodzinny w kierunku chorób sercowo-naczyniowych był ujemny. W badaniu przedmiotowym pacjent w stanie ogólnym średnim. Stwierdzono nieznacznie podwyższone wartości ciśnienia tętniczego 150/80 mm Hg z okresowo niemiarową akcją serca $75 / \mathrm{min}$. Osłuchowo nad polami płucnymi pojedyncze trzeszczenia u podstawy obu płuc ze stłumieniem wypuku w dolnym polu płuca lewego. Na kończynach dolnych obserwowano nieznaczne ciastowate 


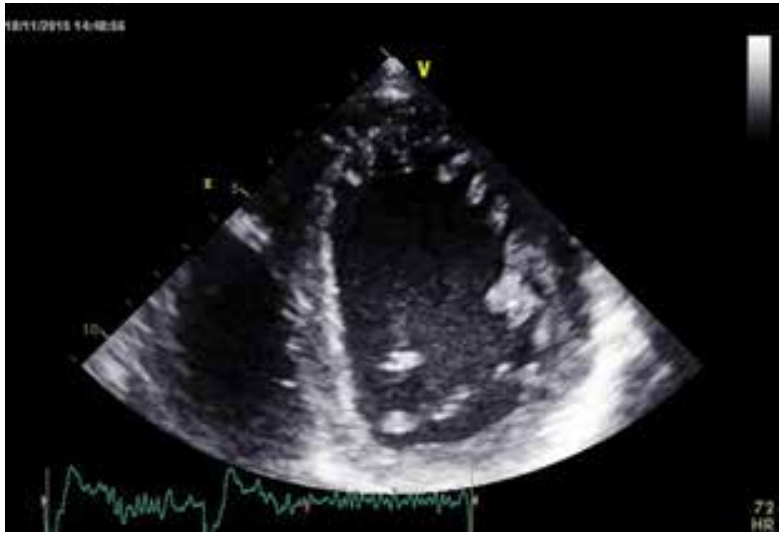

Rycina 1. Echokardiografia przezklatkowa - widoczne wzmożone beleczkowanie tworzące zatoki w koniuszku lewej komory

obrzęki. W badaniach laboratoryjnych uwagę zwracały podwyższone wartości N-końcowego propeptydu natriuretycznego typu B (NT-proBNP, N-terminal pro B-type natriuretic peptide) $15647 \mathrm{pg} / \mathrm{ml}$, czasu częściowej tromboplastyny po aktywacji (APTT, activated partial thromboplastin time) 72,7 s, międzynarodowego wskaźnika znormalizowanego (INR, international normalized ratio) 6,22, oraz gamma-glutamylotranspeptydazy (GGTP, gamma-glutamyl transpeptidase) $478 \mathrm{j}$./I przy prawidłowych wartościach aminotransferaz (AIAT 19 j./I, AspAT 29 j./l, bilirubina 1,2 mg/ /dl). W EKG rejestrowano migotanie przedsionków (AF, atrial fibrillation) z częstością komór 80/min. Lewogram patologiczny. Blok lewej odnogi pęczka Hisa. Czas trwania AF był nieznany. Przezklatkowe badanie echokardiograficzne wykazało ciężką dysfunkcję skurczową lewej komory ocenianą metodą Simsona - frakcja wyrzutowa lewej komory (LVEF, left ventricular ejection fraction) $=32 \%$. Szczególną cechą stwierdzoną w badaniu było wzmożone beleczkowanie w koniuszku lewej komory (ryc. 1) przechodzące na segmenty przykoniuszkowe i środkowe ściany bocznej, przedniej i dolnej lewej komory oraz całą wolną ścianę prawej komory. W segmentach objętych wzmożonym beleczkowaniem uwidoczniono podział ściany lewej komory na dwie warstwy - zewnętrzną zbitą, scaloną oraz wewnętrzną niescaloną ze stosunkiem grubości warstwy niescalonej do scalonej powyżej 2 (ryc. 2). W wykonanym rezonansie magnetycznym potwierdzono ostatecznie echokardiograficzne rozpoznanie niescalonego mięśnia prawej i lewej komory.

W trakcie kolejnej hospitalizacji wykonano kardiowersje elektryczną, uzyskując powrót rytmu zatokowego z zaburzeniami przewodnictwa przedsionkowo-komorowego do bloku

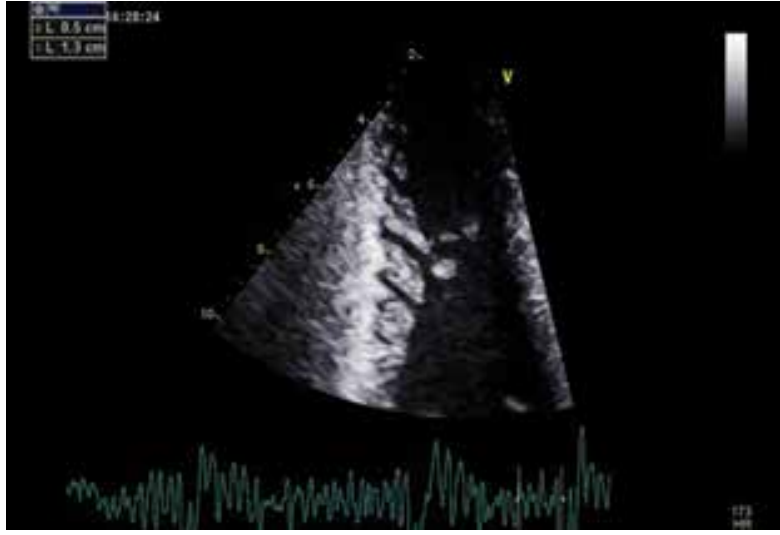

Rycina 2. Echokardiografia przezklatkowa (zoom na segment podstawny wolnej ściany prawej komory) - widoczna dwuwarstowa budowa ściany. Stosunek warstwy niescalonej do scalonej przekracza 2

III stopnia włącznie (ryc. 3). Koronarografia nie uwidoczniła zmian w naczyniach wieńcowych. Pacjent został ostatecznie zakwalifikowany do implantacji kardiowertera-defibrylatora.

\section{Omówienie}

Izolowany niescalony mięsień lewej komory (ILVNC, isolated left ventricular noncompaction) to rzadko występujące schorzenie zaliczone przez American Heart Association do pierwotnych genetycznych kardiomiopatii, natomiast przez European Society of Cardiology zakwalifikowane jako kardiomiopatia niesklasyfikowana [1, 2]. Zmiany dotyczą struktury mięśnia lewej komory, który składa się z bardzo rozbudowanych beleczek mięśniowych oraz głębokich zachyłków międzybeleczkowych, tworząc dwie warstwy: scaloną - epikardialną, cienką, zbudowaną prawidłowo - i niescaloną - endokardialną, grubą, o nieprawidłowej budowie beleczkowej (ryc. 4). W części przypadków obserwuje się również zwiększoną liczbę beleczek i zachyłków w prawej komorze $[3,4]$. Ponadto charakterystyczny jest napływ krwi do zachyłków międzybeleczkowych i dalej w głąb „gąbczastej” struktury. Nie stwierdza się obecności połączeń z nasierdziowymi naczyniami wieńcowymi. Niescalenie mięśnia prawej komory występuje w skojarzeniu z wrodzonymi wadami serca z nadciśnieniem płucnym, z zawężaniem drogi odpływu prawej lub lewej komory, wrodzonymi złożonymi wadami siniczymi oraz wadami tętnic wieńcowych [5]. W opisanym przypadku nie stwierdzono wyżej wymienionych chorób współistniejących. Niescalenie mięśnia prawej i lewej komory może zostać zdiagnozowane w wieku dorosłym ze względu na późną manifestację kliniczną [3]. 

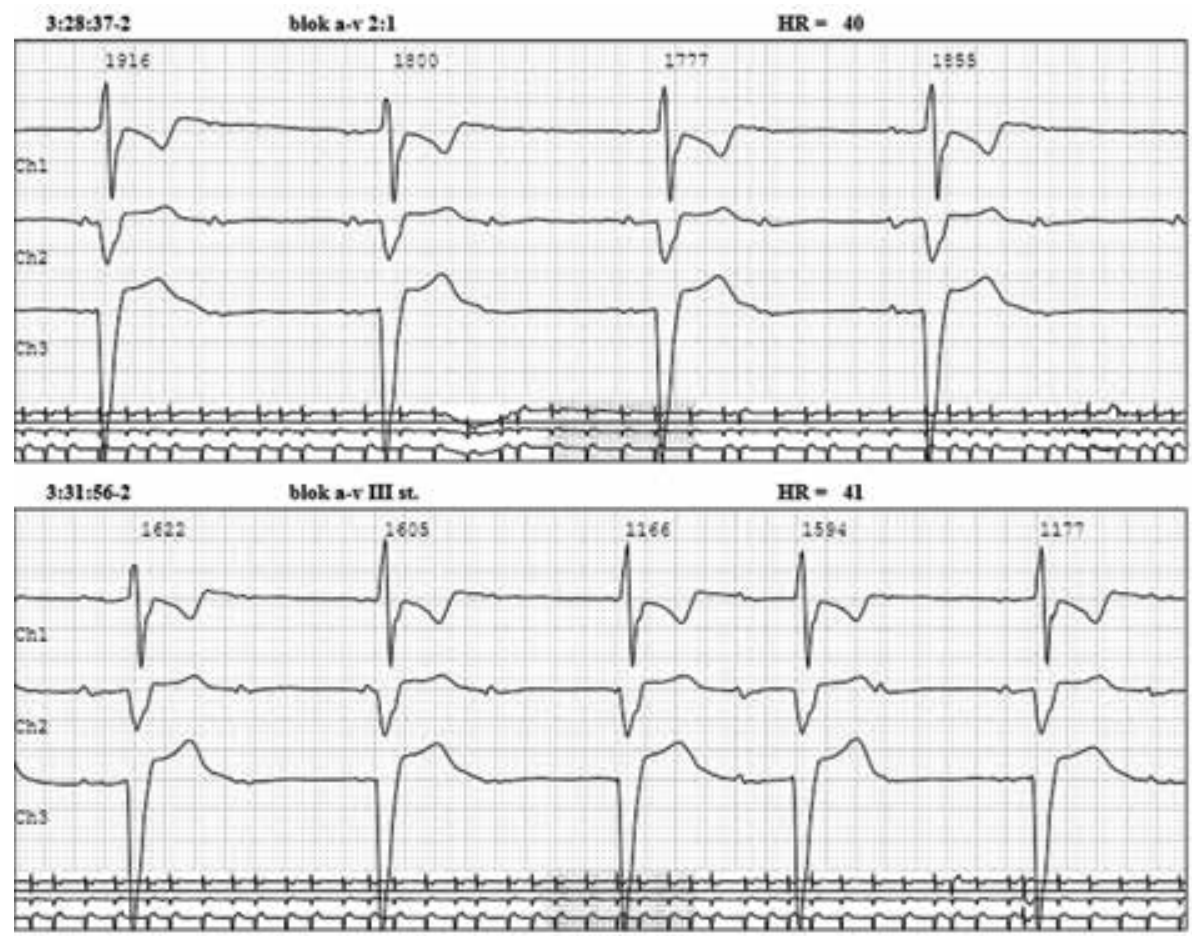

Rycina 3. Badanie EKG metodą Holtera - zarejestrowane epizody bloku przedsionkowo-komorowego 2:1 i bloku całkowitego

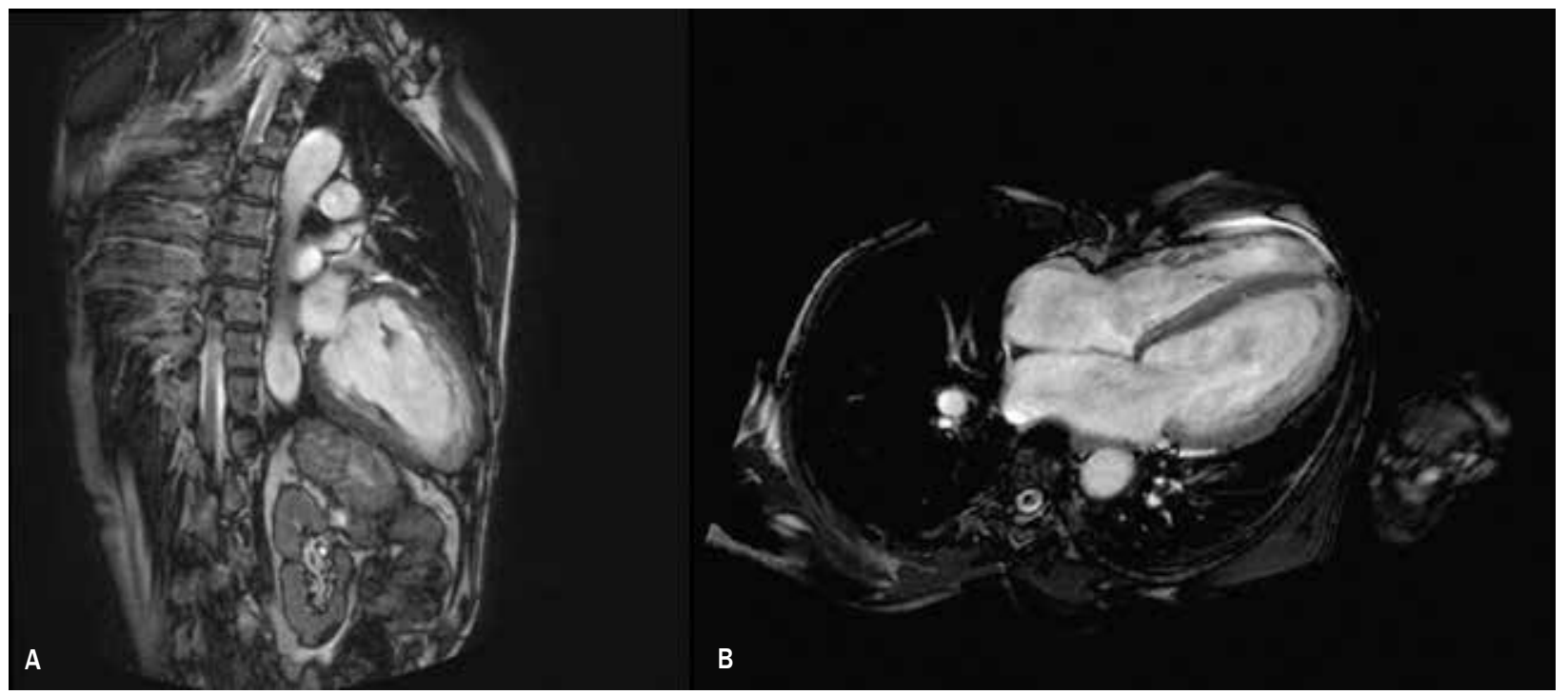

Rycina 4A. Sekwencja kinematograficzna CINE (cinecoronaryarteriography) obrazująca zwiększony stosunek szerokości warstwy niescalonej do zbitej miokardium w zakresie lewej komory; B. Sekwencja PSIR (phase-sensitive inversion recovery) obrazująca śródmięśniowe pasma późnego wzmocnienia pokontrastowego o charakterze zmian włóknistych w zakresie przegrody międzykomorowej (IVS, interventricular septum) 


\section{Abstract}

The paper presents a case of a patient with left and right ventricular non-compaction. The suspicion of final diagnosis was pulled out basing on echocardiography and overall clinical picture. Magnetic resonance imaging confirmed ventricular non-compaction. Symptomatic treatment was employed. Patient was directed for cardioverter defibrillator implantation because of third-degree atrioventricular block observed in Holter monitoring. Currently he is under close observation.

Key words: diagnosis, ventricular non-compaction, magnetic resonance imaging

Folia Cardiologica 2016; 11, 4: 334-337

\section{Piśmiennictwo}

1. Collins P. Embriology: development of the heart. W: Williams P.L. (red.). Gray's anatomy. 38th Ed. Churchill Livingstone, London 1995: 182.

2. Lubiszewska B., Hoffman P., Rużyłło W. Isolated noncompaction of the ventricular myocardium. Case report and review of literature. Kardiol. Pol. 2001; 55: 443-446.

3. Włodarska E.K., Woźniak O., Konka M. i wsp. Isolated ventricular noncompaction mimicking arrhythmogenic right ventricular cardiomyopaty. Int. J. Cardiol. 2010; 145: 107-111.
4. Jenni R., Oechslin E., Schneider J. i wsp. Echocardiographic and pathoanatomical characteritics of isolated left ventricular noncompaction: a step towards classification as a distinct cardiomyopathy. Heart 2001; 86: 666-671.

5. Weiford B.C., Subbarao V.D., Mulhern K.M. Noncompaction of the ventricular myocardium. Circulation 2004; 109: 2965-2971. 